\title{
EVALUATION OF ENDOCRINE CHANGES IN LIQUIDATORS: THE EARLY AND LATE POST-ACCIDENT PERIOD
}

\author{
N.M. Hovhannisyan', A.G. Karapetyan ${ }^{1 *}$, V.S.Grigoryan ${ }^{2}$
}

${ }^{1}$ Scientific Center of Radiation Medicine and Burns, Yerevan, Armenia

${ }^{2}$ Yerevan State Medical University after Mkhitar Heratsi, Yerevan, Armenia

\begin{abstract}
The aim of the current research was the detection and assessment of endocrine dysfunctions of disaster fighters of Chernobyl nuclear power plant catastrophe depending on radiation and non-radiation factors in the early and distant post-disaster periods with the help of system analysis methods.

One can come across works dedicated to the study of endocrine dysfunctions of organisms exposed to a high level of radiation, but there are not enough data about the changes in endocrine indices in the case of low level radiation. This is the reason why it is of interest to find out the role of endocrine indices in the development of radiobiological effects in the case of low dosage exposure with the help of system analysis methods in disaster fighters of Chernobyl nuclear power plant catastrophe (liquidators).

The results of correlation, dispersion and multi regression analyses of endocrine indices are presented in the study. The hypothyroidism model is presented.
\end{abstract}

Key words: Endocrinological disorders, liquidators, radiation and age factors, algorithms, hypothyroidism, hyperthyroidism

DOI: $10.21175 /$ RadProc.2016.03

\section{INTRODUCTION}

30 years have passed since the global radioecological catastrophe on the Chernobyl nuclear power plant. It was assumed that the main consequence of the impact would be the one of radioactive iodine and cesium and the main target organ would be the thyroid gland [1]. At the present time there is no doubt about the fact that one of the medical consequences of the disaster is the increased incidence of thyroid cancer among children and adolescents, who lived on the territory of Belarus, Russia and Ukraine at the time of the disaster and were exposed to radioactive contamination $[2,3]$.

In case of radiation impact the level of hypothyroidism intensity plays an important role. It defines a big capture of radioactive iodine of hyperplastic thyroid gland and therefore increase in the absorbed radiation. Summing up the data of many authors Orginazzi [4] emphasized that there is no low threshold of radiation for the thyroid gland dysfunction. At the same time the endocrine system is uniform and its other components can't remain intact.

The aim of the current research was to identify the endocrine disorders of the liquidators depending on radiation and a number of non radiation factors in the early (1987-1988) and distant (2005-2006) post disaster periods.

\section{MATERIALS AND METHODS}

About 3000 disaster fighters of Chernobyl nuclear power plant catastrophe have been under observation at the Scientific Centre of Radiation Medicine and Burns since 1986. All the liquidators annually undergo clinical lab examinations (biochemical, immunological and endocrine indices of the blood etc.). The following hormones were examined among 120 liquidators: thyroxin $\left(\mathrm{T}_{4}\right)$, triiodothyronine $\left(\mathrm{T}_{3}\right)$, thyroid-stimulating hormone (TSH), adrenocorticotropic hormone (ACTH), somatotropic hormone, prolactin, calcitonin, parathyroid hormone, cortisol and testosterone.

The control group was comprised of 30 residents of Armenia aged 30-50 (men having no contact with ionizing radiation). The studies were carried out using the radioimmunoassay method (RIA) [5].

For statistical system analysis of the data the liquidators were divided into 4 age groups ( the year of birth 1930-1940, 1941-1950, 1951-1960, 1961-1970) which were then divided into 3 subgroups in accordance with the year of their stay in the disaster area $(1986 ; 1987 ; 1988$ to identify the radiation factor influence). Correlation, variance factor and multiple regression analyses were carried out. The statistical result processing was done with the help of statistical packages SPSS, MedCalc, StatSoft $[6,7]$.

\footnotetext{
*ncrmio@web.am
} 


\section{RESUlTS AND DisCUSSION}

During the first medical examination immediately following the disaster $22.4 \%$ of the liquidators who participated in the Chernobyl power plant disaster liquidation in 1986 had thyroid gland hyperplasia of III degree without function disorders. This obviously has nothing to do with the radiation influence since the external radiation dose to which the liquidators were exposed cannot cause significant morphological changes in such a short period of time. The observed thyroid gland hyperplasia was obviously stipulated by the goitrous endemy which occurred before the disaster as well and only careful medical examination made it possible to detect it.

Over the years that have passed after the Chernobyl disaster an increase in the rate of endocrine disease has been observed in the liquidators of its consequences. By 2015 sickness rate of this system was $12.8 \%$ among the Armenian liquidators. Not only are thyroid gland illnesses (euthyroidism, diffuse and nodular goiter, hypothyroidism) observed among the liquidators but 2nd type pancreatic diabetes, sexual dysfunction and so on.

As a result of the radioactive iodine influence on the thyroid gland a change in the functional activity is observed in the thyroidal system. To assess the hormonal spectrum an estimation of thyroid stimulating hormone (TSH), general thyroxin( 44 ), general triiodothyronine ( $\left.\mathrm{T}_{3}\right)$ and free fractions of $\mathrm{T}_{3}$ and $\mathrm{T} 4$ was performed [8].

To assess the dynamics of the change in the indices $\mathrm{T}_{3}, \mathrm{~T}_{4}$ and TSH over 25 years we applied regression analysis getting the formulae $\mathrm{T}_{3}=1.47-$ 0.014x; TSH=2.93-0.09x; T4=121.7-0.52x where $\mathrm{x}$ stands for the years following the disaster. 95\% confidence level embraces all the values of these indices. It can be concluded from the formulae that there is a gradual decrease of these indices and further reduction of these indices can be predicted at least in the next 3-5 years.

A year after the liquidators returned from the disaster area there was a tendency indicating dosage dependence of the thyroid gland hormones. That is why it was decided to use the method of variance factor analysis which gives an opportunity to break down the variation of the object in question into influence portions of radiation and age factors. We succeeded in identifying the influence portions of radiation and age factors on the change of the indices $\mathrm{T}_{3}, \mathrm{~T}_{4}$ and $\mathrm{TSH}$ in dynamics during all the years of study.

The factor analysis have shown that the liquidators working on the reactor right after the disaster had a much higher increase in the thyroid gland function. The impact of the radiation factor on the rise of these three indices was manifested in different ways. The increase of the radiation factor on the index $\mathrm{T}_{3}$ was observed from 1988 to 1992. Further a decrease of the radiation factor and increase of the age factor is noted which coincides with the literature data $[9,10]$. The portion of the radiation factor influence on $\mathrm{T} 4$ and TSH from the first year of the post disaster period had reliable values ( $54.8 \%$ and $73.04 \%$ respectively). The highest point of $\mathrm{T}_{4}$ was noticed in 1990 and later on there was a steady decline of this index. A higher value of the radiation factor influence portion on TSH was replaced by a sharp decline in the next 2-3 years, then an increase of its value was observed up to $54.28 \%$. Further the radiation factor decreased gradually giving way to the age factor. In colour stack mode (Figure 1) one can see that the radiation factor influence prevailed for these 3 indices in the first years after the disaster but as the years went by age became more significant.

The thyroid system changes observed in the first months after the disaster can be characterized as euthyroid hyperthyroxinemia in the liquidators - an increase in the level of thyroxin in blood without any clinical signs of hyperthyroidism which gradually decreased in the course of time.

The "wave of hyperthyroxinemia" a few months after the disaster can be interpreted as one of the manifestations of endocrine maladjustment.
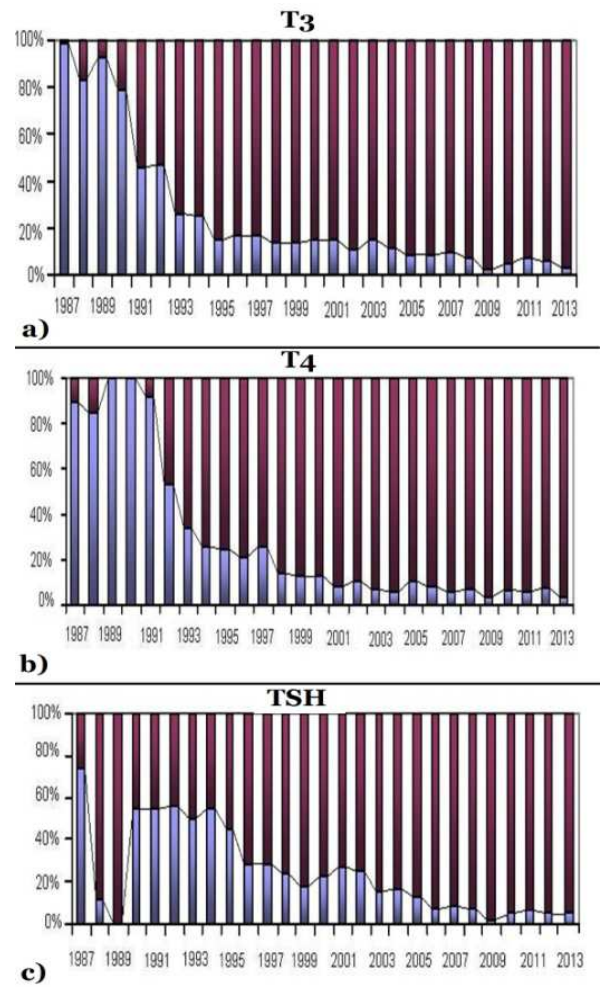

Figure 1. Influence portions of radiation and age factors on $\mathrm{T}_{3}, \mathrm{~T} 4$ and TSH in the "colour stack" mode

It is common to assess TSH in combination with the changes in $\mathrm{T}_{3}$ and $\mathrm{T}_{4}$. That is why in order to assess the level of mutual influence of these indices a multi regression analysis was carried out among the indices $\mathrm{T}_{3}, \mathrm{~T}_{4}$ and $\mathrm{TSH}$ in the early and distant periods. The following regression formulae are derived $Z=3.25-0.136 \mathrm{x}-0.001 \mathrm{y}$ for the early post disaster period and $\mathrm{Z}=2.29+0.681 \mathrm{x}-0.004 \mathrm{y}$ for the distant period where $\mathrm{x}$ stands for $\mathrm{T} 3, \mathrm{y}-\mathrm{T} 4$, and $\mathrm{z}-$ TSH respectively (Figure 2).

From our point of view, the decline in TSH levels in the blood observed in the early stages was of a compensatory character and was caused by an increase in the content of total thyroxine. This indicated that the normal pituitary-thyroid relationships are preserved in the examined liquidators. 
The index $\mathrm{T} 4$ free was also examined. It is the part of thyroxin which circulates in blood in protein free condition. This very fraction of $\mathrm{T}_{4}$ provides the metabolic activity of the hormone i.e. it influences the cells of various organs. An increase in the free $\mathrm{T} 4$ content is observed in case of hyperthyroidism which is a condition when an enhanced synthesis of the thyroid gland hormones takes place. According to literature data the illnesses of adrenal glands with an increased cortisol release, as well as significant iodine shortage in the body can lead to the decline in the free thyroxin concentration. Unfortunately, this index was only studied by us in the recent years and it was not possible to follow its change dynamics (the mean value is shown in Table 1). In the distant period decline in the level of free thyroxin i.e. hypothyroidism is observed. Quite often the lack of free $\mathrm{T}_{4}$ is connected with thyroiditis which is an inflammatory disease of the thyroid gland whose source is an infectious or autoimmune process.

The institute of clinical endocrinology of Scientific Endocrine Centre of Russian Academy of Medical Sciences offered a standard regimen of hypothyroidism diagnostics [11] which we presented as model algorithm (Figure 3).
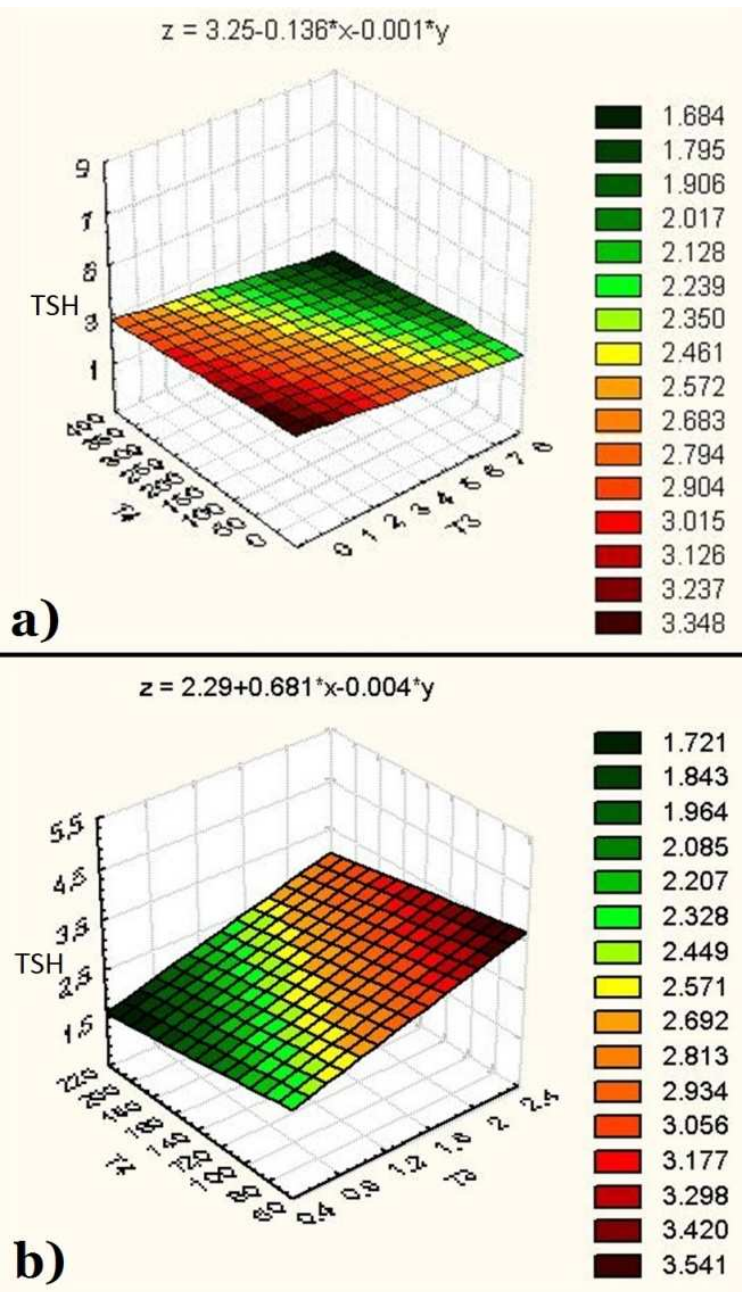

Figure 2. Results of the multi regression analysis in early and distant post disaster periods
Table 1. Changes in other endocrinological parameters in early and distant post disaster periods.

\begin{tabular}{|l|l|l|l|}
\hline Parameters & Norm & $\begin{array}{l}\text { Early } \\
\text { period }\end{array}$ & $\begin{array}{l}\text { Late } \\
\text { period }\end{array}$ \\
\hline Calcitonin & O-20 pg/ml & $\begin{array}{l}18.08 \\
\pm 3.75\end{array}$ & $\begin{array}{l}9.587 \\
\pm 2.497\end{array}$ \\
\hline $\begin{array}{l}\text { Parathyroid } \\
\text { hormone }\end{array}$ & $8-76 \mathrm{pg} / \mathrm{ml}$ & 68.082 & 42.79 \\
\pm 16.31 & \pm 8.41 \\
\hline STH & O-2.0 ng/ml & 1.3 & 1.1 \\
& & \pm 0.21 & \pm 0.57 \\
\hline Free T4 & $16.0-25.0$ & & 15.1 \\
& pmole/l & & \pm 3.4 \\
\hline Cortisol & $190-750$ & 701.65 & 683.74 \\
& nmole/l & \pm 15.65 & \pm 22.85 \\
\hline ACTH & O-25.8 & 26.6 & 17.92 \\
& pg/ml & \pm 4.1 & \pm 0.798 \\
\hline Prolactin & $100-265$ & 149.49 & 176.35 \\
& mmbetta/L & \pm 12.44 & \pm 16.45 \\
\hline Testosterone & $6.9-34.6$ & 16.5 & 11.16 \\
& nmol/l & \pm 1.02 & \pm 3.76 \\
\hline
\end{tabular}

A non thyroid disease is a somatic disease in the case of which transitory, temporary changes can be registered in the general $\mathrm{T} 4$ and $\mathrm{TSH}$ concentration which as a rule depends on the gravity of the disease course. According to this algorithm by the end of the examination the liquidators show a tendency to secondary hypothyroidism which can be accounted for by the imposition of such components as age changes, the impact of the precinctive factor, that of the radiation factor and probably others.

During the examination of the adrenal hormone concentration in the liquidator and control group in 1987 and 5 years after the disaster it was revealed that though the mean concentration of the cortisol in both groups (control and liquidators) was in the range of standard values, in the early post disaster period there was a tendency of its increase in the liquidators (in the control group: 648.2 \pm 23.58 ). The value of ACTH in the early post disaster period also differed from the control values (in the control group: $16.9 \pm 3.2$ ). By the distant period the differences between the ACTH and cortisol values of the liquidators and the control group had become insignificant. And in spite of the level normalization of these hormones in the distant period, there was a direct correlation between these indices $(\mathrm{r}=0.998)$ in the course of the whole examination, which fully conforms to the view that cortisol secretion is stimulated by ACTH. 


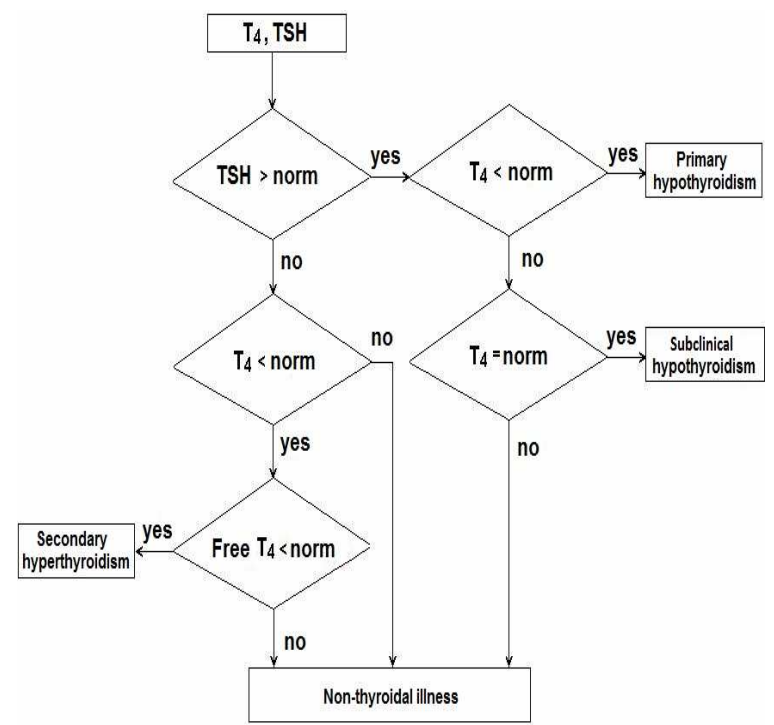

Figure 3. The algorithm of diagnostics of hypothyroidism

We made an attempt to reveal the influence portion of the radiation and age factors on the change of concentration of cortisol with the help of variance factor analysis and compare them with the indices obtained in the distant post disaster period.

Variance factor analysis revealed that in the early post disaster period the influence portion of the radiation factor on cortisol is $39.2 \%$, and that of the age factor is $45.6 \%$.

In the distant period both factors lose their influence on the change in the cortisol concentration. The percentage of the portion of both factors declined twice as much by the end of the examination (radiation factor $-5.8 \%$, the age factor $-20.1 \%$ ). Obviously other influence mechanisms on this index are activated here.

Table 1 shows the results of the changes in the prolactin and testosterone indices in the liquidators in the early and distant post disaster periods. The value of both indices right after the disaster is considerably lower than that of the control (in the controls: prolactin $-182.5 \pm 11.4$, and testosterone $-20.8 \pm 2.01$ )

In the distant period the further decline of the testosterone level can be accounted for by the transition into a different age category (since in case of physiological ageing there is a gradual decline in the sex hormone level).

\section{CONCLUSION}

In this paper, the assessment of endocrine index changes is performed in the research with the use of system analysis methods.

The long research shows that there is gradual decline in $\mathrm{T}_{3}, \mathrm{~T}_{4}$, and $\mathrm{TSH}$. The obtained regression formulae give an opportunity to predict further decline of these indices at least in the next 3-5 years. Through the dispersion factor analysis we found out that in the first years after the disaster radiation factor influence prevailed on the change of these indices but after 30 years the influence of the age factor has become more significant.
According to the algorithm of hypothyroidism diagnostics by the end of the examinations the liquidators show a tendency to secondary hypothyroidism which can be accounted for by the imposition of such components as: age change, precinctive factor impact and radiation factor impact.

During the examination of the adrenal hormone concentration in the liquidator and control group in 1987 and 5 years after the disaster it was revealed that though the mean concentration of the cortisol in both groups (control and liquidators) was in the range of standard values, in the early post disaster period there was a tendency of its increase in the liquidators. The value of ACTH in the early post disaster period also differed from the control values. By the distant period the differences between the ACTH and cortisol values of the liquidators and the control group had become insignificant. And in spite of the level normalization of these hormones in the distant period, there was a direct correlation between these indices in the course of the whole examination, which fully conforms to the view that cortisol secretion is stimulated by ACTH.

In the distant period there is a tendency to normalization, but some decline of the index level can be accounted for by the transition into a different age category (since in case of physiological ageing there is a gradual decline in the sex hormone level).

\section{REFERENCES}

1. A.E. Romanenko, N.D. Tronko and V.V. Marks, "Radiation Medicine in an Objective Estimation of Consequences of Chernobyl Accident," Int. Mag. Rad. Med., vol. 5, pp. 3-25, 2000

2. Медицинские радиологические последствия Чернобыля: прогноз и фактические данные спустя $3 о$ лет, В.К. Иванов и А.Д. Каприн, Ред., Москва, Россия: ГЕОС, 2015 (Medical Radiological Consequences of Chernobyl: The Forecast and the Real Data Later 30 Years, V.K. Ivanov, A.D. Kaprin, Eds., Moscow, Russia: GEOS, 2015)

3. E. Ron, "Thyroid Cancer Incidence among People Living in Areas Contaminated by Radiation from the Chernobyl Accident," Health Phys., vol. 93, no. 5, pp. 502-511, Nov. 2007

4. J. Orginazzi, Tempo med., no. 229, pp.19-29, 1996

5. An Introduction to Radioimmunoassay and Related Techniques, T. Chard, Ed., 5th ed., Amsterdam, The Nederlands: Elsevier Sci., 1995

6. М.Б. Славин, Методы системного анализа в медицинских исследованиях, Москва, Россия: Медицина, 1989 (M.B. Slavin, Methods of the System Analysis in Medical Research, Moskow, Russia: Medicina, 1989)

7. Е.А. Вуколов, Основы статистического анализа, Москва, Россия: Форум, 2004 (E.A. Vukolov, Basics of the Statistical Analysis, Moscow, Russia: Forum, 2004)

8. Патология отдаленного периода у ликвидаторов последствий аварии на Чернобыльской АЭС, А.М. Никифоров, Ред., Москва, Россия: Бином, 2002 (Pathology of the Postponed Period at Liquidators of Chernobyl NPP Accident Consequences, A.M. Nikiforov, Ed., Moscow, Russia: BINOM, 2002

9. Т.З. Сейсембеков, Б.К. Аканов, Г.Е. Садвакасова, „Изменение размеров щитовидной железы у лиц различного возраста экологических условиях Центрального Казахстана,“ Современные проблемы экологии Центрального Казахстана - Науч. конф., Караганда, Казахстан, 1996, с. 289-295 (T.Z. Seysembekov, B.K. Akanov, G.E. Sadvakasova, Changes in the Size of the Thyroidea at People, During Different 
Growths of the Environmental Conditions in Central Kazakhstan," Modern Problems of Ecology of the Central Kazakhstan - Sci. Conf., Karaganda, Kazakhstan, 1996, pp.289-295)

10. Г.Е. Садвакасова, „Возрастно-половые особенности параметров щитовидной железы у жителей Центрального Казахстана," Здравоохранение Казахстана, №2, с. 27-28, 1996 (G.E. Sadvakasova, "Age-Sexual Features of Parametres of a Thyroid Gland at Inhabitants of the Central Kazakhstan," Health, Prot. Kazakh., no. 2, pp 27-28, 1996
11. Е.А. Трошина, Г.Ф. Александрова, Ф.М. Абдулхабирова и Н.В. Мазурина, Синдром гипотиреоза в практике интерниста. Методическое пособие для врачей, Москва, Россия: Мин. здравоохр. Акад. мед. наук, 2002 (Е.А. Troshina, G.F. Aleksandrova, F.M. Abdulhabirova, N.V. Mazurina, The Syndrome of Hypothyroidism in Physicians Practice. Methodical Management for Physicians, Moscow, Russia: Min. Health Prot. Acad. Med. Sci., 2002 